\title{
Erratum to: Genomic innovations, transcriptional plasticity and gene loss underlying the evolution and divergence of two highly polyphagous and invasive Helicoverpa pest species
}

\author{
S. L. Pearce ${ }^{1}$, D. F. Clarke ${ }^{1,2}$, P. D. East ${ }^{1}$, S. Elfekih ${ }^{1}$, K. H. J. Gordon ${ }^{1 *}$, L. S. Jermiin ${ }^{1}$, A. McGaughran ${ }^{1,3}$, \\ J. G. Oakeshott ${ }^{1 *}$, A. Papanicolaou ${ }^{1,4}$, O. P. Perera ${ }^{5}$, R. V. Rane ${ }^{1,2}$, S. Richards ${ }^{6 *}$, W. T. Tay ${ }^{1}$, T. K. Walsh ${ }^{1}$, A. Anderson? ${ }^{1}$, \\ C. J. Anderson ${ }^{1,7}$, S. Asgari ${ }^{8}$, P. G. Board ${ }^{9}$, A. Bretschneider ${ }^{10}$, P. M. Campbell ${ }^{1}$, T. Chertemps ${ }^{11,12}$, J. T. Christeller ${ }^{13}$, \\ C. W. Coppin', S. J. Downes ${ }^{14}$, G. Duan³ , C. A. Farnsworth ${ }^{1}$, R. T. Good², L. B. Han ${ }^{15}$, Y. C. Han ${ }^{1,16}$, K. Hatje ${ }^{17}$, \\ I. Horne', Y. P. Huang ${ }^{18}$, D. S. T. Hughes ${ }^{6}$, E. Jacquin-Joly ${ }^{12}$, W. James' ${ }^{1}$, S. Jhangiani', M. Kollmarr ${ }^{17}$, S. S. Kuwar ${ }^{10}$, \\ S. Li ${ }^{1}$, N-Y. Liu' ${ }^{1,19}$, M. T. Maibeche ${ }^{11,12}$, J. R. Miller ${ }^{20}$, N. Montagne ${ }^{11}$, T. Perry², J. Qu' ${ }^{6}$, S. V. Song ${ }^{2}$, G. G. Sutton ${ }^{20}$, \\ H. Vogel ${ }^{10}$, B. P. Walenz ${ }^{20}$, W. Xu ${ }^{1,21}$, H-J. Zhang ${ }^{1,22}$, Z. Zou ${ }^{15}$, P. Batterham², O. R. Edwards ${ }^{23}$, R. Feyereisen ${ }^{24}$, \\ R. A. Gibbs ${ }^{6}$, D. G. Heckel ${ }^{10}$, A. McGrath', C. Robin², S. E. Scherer ${ }^{6}$, K. C. Worley ${ }^{6}$ and Y. D. Wu ${ }^{16}$
}

\section{Erratum}

Upon publication of the original article [1], it was noticed that Dr Papanicolaou's surname was spelt incorrectly. The correct spelling is "Papanicolaou", as shown in the author list of this erratum.

\begin{abstract}
Author details
${ }^{1}$ CSIRO Black Mountain, GPO Box 1700, Canberra, ACT 2600, Australia. ${ }^{2}$ School of Biological Sciences, University of Melbourne, Parkville, Vic, Australia. ${ }^{3}$ Research School of Biology, Australian National University, Canberra, ACT, Australia. ${ }^{4}$ Hawksbury Institute for the Environment, Western Sydney University, Penrith, NSW, Australia. ${ }^{5}$ Southern Insect Management Research Unit, USDA-ARS, Stoneville, MS, USA. ${ }^{6}$ Human Genome Sequencing Center, Baylor College of Medicine, Houston, TX, USA. ${ }^{7}$ Biological and Environmental Sciences, University of Stirling, Stirling, UK. ${ }^{8}$ School of Biological Sciences, University of Queensland, Brisbane St Lucia, QLD, Australia. ${ }^{9}$ John Curtin School of Medical Research, Australian National University, Canberra, ACT, Australia. ${ }^{10}$ Max Planck Institute of Chemical Ecology, Jena, Germany. ${ }^{11}$ Sorbonnes Universités, UPMC Université Paris 06, Institute of Ecology and Environmental Sciences of Paris, Paris, France. ${ }^{12}$ National Institute for Agricultural Research (INRA), Institute of Ecology and Environmental Sciences of Paris, Versailles, France. ${ }^{13}$ Plant and Food Research, Mt Albert, Auckland, New Zealand. ${ }^{14}$ CSIRO, Narrabri, NSW, Australia. ${ }^{15}$ State Key Laboratory of Integrated Management of Pest Insects and Rodents, Institute of Zoology, Chinese Academy of Sciences, Beijing 100101, China. ${ }^{16}$ College of Plant Protection, Nanjing Agricultural University, Nanjing, Jiangsu, China. ${ }^{17}$ Max Planck Institute for Biophysical Chemistry, Gottingen, Germany. ${ }^{18}$ Institute of
\end{abstract}

Plant Physiology and Ecology, Shanghai Institutes of Biological Sciences, Chinese Academy of Sciences, Shanghai, China. ${ }^{19}$ Key Laboratory of Forest Disaster Warning and Control of Yunnan Province, Southwest Forestry University, Kunming 650224, China. ${ }^{20} \mathrm{~J}$. Craig Venter Institute, Rockville, MD, USA. ${ }^{21}$ School of Veterinary and Life Sciences, Murdoch University, Perth, WA, Australia. ${ }^{22}$ Chongqing Key Laboratory of Biochemistry and Molecular Pharmacology, Chongqing Medical University, Chongqing 400016, China. ${ }^{23} \mathrm{CSIRO}$, Floreat Park, WA, Australia. ${ }^{24}$ Department of Plant and Environmental Sciences, University of Copenhagen, Thorvaldsensvej, Denmark.

Received: 1 August 2017 Accepted: 7 August 2017

Published online: 15 August 2017

\section{Reference}

1. Pearce SL, Clarke DF, East PD, Elfekih S, Gordon KHJ, Jermiin LS, McGaughran A, Oakeshott JG, Papanikolaou A, Perera OP, Rane RV, Richards S, Tay WT, Walsh TK, Anderson A, Anderson CJ, Asgari S, Board PG, Bretschneider A, Campbell PM, Chertemps T, Christeller JT, Coppin CW, Downes SJ, Duan G, Farnsworth CA, Good RT, Han LB, Han YC, Hatje K, Horne I, Huang YP, Hughes DST, Jacquin-Joly E, James W, Jhangiani S, Kollmar M, Kuwar SS, Li S, Liu NY, Maibeche MT, Miller JR, Montagne N, Perry T, Qu J, Song SV, Sutton GG, Vogel H, Walenz BP, Xu W, Zhang HJ, Zou Z, Batterham P, Edwards OR, Feyereisen R, Gibbs RA, Heckel DG, McGrath A, Robin C, Scherer SE, Worley KC, Wu YD. Genomic innovations, transcriptional plasticity and gene loss underlying the evolution and divergence of two highly polyphagous and invasive Helicoverpa pest species. BMC Biol. 2017;15:63. doi:10.1186/s12915-017-0402-6.

\footnotetext{
* Correspondence: karl.gordon@csiro.au; john.oakeshott@csiro.au; stephenr@bcm.edu

'CSIRO Black Mountain, GPO Box 1700, Canberra, ACT 2600, Australia

${ }^{6}$ Human Genome Sequencing Center, Baylor College of Medicine, Houston,

TX, USA
} 